\title{
Hubungan Model Pembelajaran Tuntas Dan Penggunaan Metode Discovery Terhadap Karakter Siswa SMA Kristen Citra Bangsa Kupang
}

\author{
Asti Yunita Benu ${ }^{(1)}$ \\ ${ }^{1}$ STKIP Citra Bina Nusantara Kupang \\ Email: ${ }^{1}$ astiyunitabenu@gmail.com \\ DOI:http://doi.org/10.28926/riset_konseptual.v2i4.116
}

\begin{abstract}
ABSTRAK
Penelitian ini bertujuan untuk mengetahui sejauh mana hubungan model pembelajaran tuntas dan metode discovery terhadap karakter siswa di SMA Kristen Citra Bangsa Kupang. Penelitian ini adalah penelitian kuantitatif korelasi menggunakan metode angket. Teknik pengujian data dalam penelitian ini yaitu uji reliabilitas angket, validitas angket, uji normalitas, uji homogenitas dan uji $t$ statistik. Hasil dari analisa setelah dikorelasikan diperoleh, korelasi $\mathrm{X} 1$ terhadap $\mathrm{Y}, \mathrm{t}$ hitung $=2,819$ sedangkan $t$ tabel pada taraf kesalahan $5 \%(\alpha, 0,05)=1,721$. Korelasi yang kedua antara $X 2$ terhadap $\mathrm{Y}, \mathrm{t}$ hitung $=4,211$ sedangkan $\mathrm{t}$ tabel pada taraf kesalahan $5 \%(\alpha 0,05)=1,721$. Korelasi yang ketiga yaitu korelasi ganda antara $\mathrm{X} 1, \mathrm{X} 2$ terhadap $\mathrm{Y}$ diperoleh $\mathrm{R}$ sebesar $0,67 \mathrm{~F}$ sebesar $12,77 \mathrm{p}$ sebesar $0,000>0,05$. Berdasarkan perhitungan disimpulkan bahwa terdapat hubungan positif dan signifikan antara variabel model pembelajaran tuntas dan metode discovery terhadap karakter siswa.
\end{abstract}

\section{Kata kunci: discovery Learning, hasil belajar, kimia}

\section{PENDAHULUAN}

Pelajaran kimia di kelas X TITL 2 SMKN 1 Blitar kurang diminati siswa, karena dianggap sulit dan susah dimengerti. Hal ini ditunjukan dengan rendahnya nilai kimia siswa pada materi redoks yang mendasari materi sel Elektrokimia, dimana jumlah siswa yang mencapai nilai minimal KKM pada aspek pengetahuan sebesar $51,43 \%$ dan aspek ketrampilan sebesar $57,14 \%$ sehingga belum mencapai kriteria kentuntasan belajar secara klasikal sebesar 85\%. Rendahnya prestasi siwa kelas X TITL 2 SMKN 1 Blitar dalam pelajaran kimia tersebut menjadi bahan introspeksi peneliti selaku guru kimia di kelas tersebut untuk melakukan suatu tindakan pembelajaran yang mampu memotivasi siswa untuk belajar kimia secara aktif kreatif, dan bermakna.

Kurikulum 2013 mengamanatkan esensi pendekatan saintifik dalam pembelajaran, karena proses pembelajaran dapat dipadankan dengan suatu proses ilmiah. Pendekatan saintifik diyakini sebagai titian emas perkembangan dan pengembangan sikap, keterampilan, dan pengetahuan peserta didik. Salah satu model pembelajaran yang sesuai dengan pendekatan saintifik adalah model Discovery Learning. Penggunaan Discovery Learning, ingin merubah kondisi belajar yang pasif menjadi aktif dan kreatif. Mengubah pembelajaran yang teacher oriented ke student oriented. Merubah modus Ekspository siswa hanya menerima informasi secara keseluruhan dari guru ke modus Discovery siswa menemukan informasi sendiri (Kemendikbud, 2014). Selain itu dari hasil penelitian Enik Wijayanti, S.Pd disimpulkan bahwa penerapan metode discovery terpimpin dapat meningkatkan motivasi dan prestasi belajar siswa kelas X MIA 6 SMA Nahdlatul Ulama 1 Gresik tahun pelajaran $2014 / 2015$ pada pelajaran kimia tentang senyawa hidrokarbon. Hal ini dapat dilihat dari hasil evaluasi yang meningkat (Wijayati: 2016).

Berdasarkan uraian tentang pendekatan pembelajaran kontekstual model Discovery Learning dan temuan-temuan yang dihasilkan dalam proses pembelajaran 
kimia di kelas X TITL 2 SMKN 1 Blitar, maka penulis tertarik untuk melakukan penelitian dengan judul "Peningkatan Hasil Belajar Kimia Pada Sel Elektrokimia Melalui Model Discovery Learning di Kelas XTITL 2 SMKN 1 Blitar".

Masalah yang akan dicari penyelesaiannya dalam penelitian ini dapat dirumuskan sebagai berikut: (1) bagaimanakah penerapan model Discovery Learning pada siswa kelas X TITL2 SMKN 1 Blitar ?, (2) apakah ada peningkatan hasil belajar kimia siswa pada sel elektrokimia setelah diterapkan model Discovery Learning di kelas X TITL2 SMKN1 Blitar ? Sedangkan tujuan yang ingin dicapai dalam penelitian ini yaitu : (1) mendiskripsikan penerapan model Discovery Learning pada siswa kelas $X$ TITL2 SMKN 1 Blitar, (2) mendiskripsikan peningkatan hasil belajar kimia siswa pada sel elektrokimia setelah diterapkan model Discovery Learning di kelas X TITL2 SMKN1 Blitar.

Penelitian ini diharapkan dapat memberikan manfaat antara lain berupa : (1) dijadikan sebagai masukan untuk meningkatkan proses pembelajaran di kelas, (2) meningkatkan kemampuan siswa dalam pemahaman dan hasil belajarnya, (3) dijadikan acuan dalam melakukan penelitian sejenis, dan (4) dijadikan acuan dalam membuat kebijakan tentang peningkatan kualitas sekolah.

Pembelajaran kimia pada Kompetensi Keahlian Teknik Instalasi Tenaga Listrik (TITL) sesuai Struktur Kurikulum Pendidikan Menengah Kejuruan yang diputuskan oleh Dirjen Pendidikan Dasar dan Menengah pada tanggal 10 Februari 2017 termasuk kelompok Dasar Bidang Keahlian. Materi kimia yang diajarkan diharapkan mampu membantu siswa dalam memahami materi kelompok kompetensi keahlian (C3) atau praktek kejuruan. Adapun materi sel elektrokimia yang diajarkan di Kompetensi Keahlian Teknik Instalasi Tenaga Listrik (TITL) SMK meliputi sel Volta dan sel elektrolisa.

Alessandro Volta menemukan bahwa pasangan logam tertentu dapat membangkitkan gaya gerak listrik. Gaya gerak listrik inilah yang menyebabkan arus mengalir dalam suatu rangkaian. Arus listrik adalah aliran elektron melalui kawat (Srisumarlinah W, 2016 : hal 8). Pada saat yang sama Luigi Galvani juga menemukan hal yang sama pada reaksi spontan. Rangkaian pasangan logam yang dicelupkan ke dalam larutan elektrolit sehingga menghasilkan arus listrik inilah kemudian yang disebut sebagai sel Volta atau sel Galvani. Sedangkan elektrolisa berasal dari elektro artinya listrik dan analisis berarti uraian. sehingga elektrolisa dapat dikatakan sebagai proses penguraian suatu senyawa kimia melalui reaksi redoks karena adanya arus listrik. Maka pada elektrolisa terjadi perubahan energi dari energi listrik menjadi energi kimia.

Kurikulum 2013 mengamanatkan esensi pendekatan saintifik dalam pembelajaran, karena proses pembelajaran dapat dipadankan dengan suatu proses ilmiah. Pendekatan saintifik diyakini sebagai titian emas perkembangan dan pengembangan sikap, keterampilan, dan pengetahuan peserta didik. Salah satu model pembelajaran yang sesuai dengan pendekatan saintifik adalah model Discovery Learning. Penggunaan Discovery Learning, ingin merubah kondisi belajar yang pasif menjadi aktif dan kreatif. Mengubah pembelajaran yang teacher oriented ke student oriented. Merubah modus Ekspository siswa hanya menerima informasi secara keseluruhan dari guru ke modus Discovery siswa menemukan informasi sendiri (Kemendikbud, 2014).

Model pembelajaran Discovery Learning diaplikasikan dengan langkah-langkah pembelajaran sebagai berikut: (1) stimulation (pemberian rangsangan), (2) problem statement (identifikasi masalah), (3) data collection (pengumpulan data), (4) data processing (pengolahan data), (5) verivication (pembuktian), dan (6) generalization (menarik kesimpulan). Melalui pembelajaran Discovery Learning ini diharapkan siswa tidak hanya mempelajari apa yang terjadi dalam suatu peristiwa tetapi dapat membelajarkan siswa untuk menemukan penyebab peristiwa itu terjadi serta dampak yang ditimbulkannya, sehingga mampu menumbuhkan sikap ilmiah dan empati pada diri siswa dan pembelajaran menjadi lebih bermakna. 
IImu kimia berkaitan erat dengan fakta-fakta dan peristiwa yang ada dalam kehidupan sehari-hari. Termasuk fakta-fakta dan peristiwa yang berhubungan dengan kompetensi keahlian teknik instalsi tenaga listrik. Memahami kimia berarti mampu membuat hubungan antar ide, fakta-fakta, dan prosedurnya, pemahaman dalam belajar kimia merupakan suatu proses untuk menempatkan secara tepat informasi atau pengetahuan yang sudah dimiliki sebelumnya di dalam struktur kognitif siswa (Grouws dalam Arends, 2004: 157).

Menurut Permendikbud RI nomor 23 tahun 2016 tentang Standart Penilaian Pendidikan bab I pasal 1 ayat 2 menyatakan penilaian adalah proses pengumpulan dan pengolahan informasi untuk mengukur pencapaian hasil belajar peserta didik. Adapun penilaian terhadap peserta didik meliputi 3 aspek, yaitu; (1) sikap, (2) pengetahuan dan (3) ketrampilan. Penilaian yang wajib dilaporkan oleh guru kimia adalah penilaian pengetahuan dan ketrampilan. Di dalam mempelajari fakta-fakta yang ada diperlukan sikap yang baik dari siswa seperti jujur dalam melaporkan pengamatan, rajin dalam melaksanakan tugas dan sebagainya. Maka penilaian terhadap sikap siswa perlu disisipkan dalam fotmat penilaian ketrampilan.

\section{METODE}

Penelitian Tindakan Kelas ini dilaksanakan dalam 2 siklus pada kelas X TITL 2 SMKN 1 Blitar dengan menerapkan model pembelajaran Discovery Learning. Masingmasing siklus dilaksanakan 2 kali pertemuan. Adapun subyek penelitian ini adalah peneliti selaku guru kimia kelas X TITL 2 SMKN 1 Blitar, beserta seluruh siswa di kelas tersebut yang berjumlah 35 terdiri dari 30 siswa laki-laki dan 5 siswa perempuan.

Rancangan Penelitian Tindakan Kelas (PTK) model Kemmis dan Mc Taggart. Satu kali siklus terdiri dari : planning (perencanaan), acting (tindakan), observing (pengobservasian), dan reflekting ( perefleksian). Hasil dari perefleksian ini selanjutnya digunakan untuk memperbaiki perencanaan (revise plan) berikutnya (Kemmis \& MC.Taggart: 1990 dalam Akbar: 2010).

Instrumen yang digunakan dalam penelitian ini meliputi: lembar tes tertulis, lembar kerja kelompok, rubrik penilaian psikomotor, lembar observasi aktivitas guru dan catatan lapangan.

Teknik analisis data pada penelitian ini deskriptif secara kualitatif. Data aktivitas guru dari hasil kegiatan observasi dianalisis menggunakan teknik persentase sebagai berikut:

Persentase Nilai Rata-rata $(N R)=\frac{\text { Jumlah Skor }}{\text { Skor Maksimal }} \quad x \quad 100 \%$

Dengan taraf keberhasilan sebagai berikut:

$90 \% \leq \mathrm{NR} \leq 100 \% \quad$ : Sangat Baik

$80 \% \leq \mathrm{NR}<90 \% \quad$ : Baik

$70 \% \leq \mathrm{NR}<80 \% \quad$ : Cukup

$60 \% \leq \mathrm{NR}<70 \% \quad$ : Kurang

$0 \% \leq N R<60 \% \quad$ : Sangat Kurang

Data hasil belajar siswa dari hasil tes akhir maupun penilaian psikomotor setiap siklus dianalisis dengan menggunakan rumus:

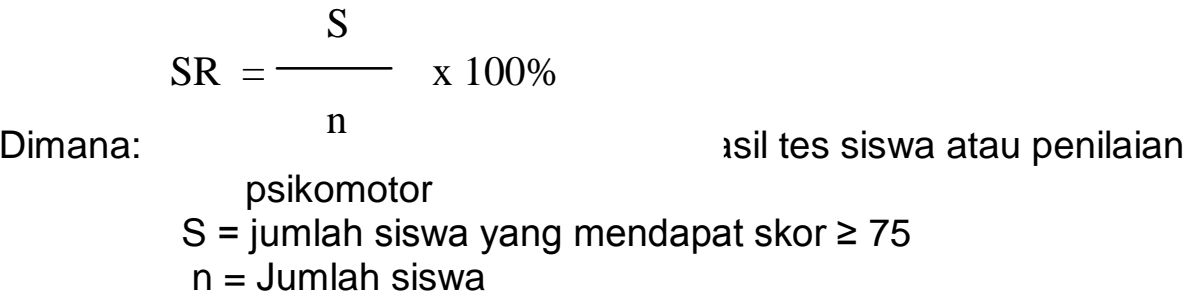

Pembelajaran dikatakan berhasil ( tuntas) jika sekurang-kurangnya $85 \%$ siswa dalam satu kelas telah mencapai nilai minimal KKM yaitu $\geq 75$. Selain itu mengacu pada Panduan Penilaian Hasil Belajar pada Sekolah Menengah Kejuruan yang 
dikeluarkan Kemendikbud tahun 2017 maka kategori penilaian dengan nilai KKM 75 dan pembulatan angka kesatuan terdekat sebagai berikut :
Kurang dari 75
: Kurang ( belum mencapai KKM
75 s.d 88
: Baik (mencapai KKM)
89 s.d 100
: Sangat baik (melampui KKM)

\section{Paparan Data Prasiklus}

HASIL

Penilaian awal yang digunakan adalah penilaian dari materi sebelumnya yaitu redoks. Hasil akhir nilai ketrampilan menunjukan hanya 20 siswa ( 57,14 \%) dan dari hasil nilai pengetahuan menunjukan hanya 18 siswa $(51,43 \%)$ yang mencapai nilai minimal KKM yang berarti belum memenuhi syarat ketuntasan belajar secara klasikal. Berdasarkan hasil observasi awal kelas X TITL 2 SMKN 1 Blitar tersebut peneliti berkesimpulan hasil pembelajaran kimia masih kurang, sehingga memenuhi syarat untuk dijadikan subyek penelitian tindakan kelas dengan model pembelajaran Discovery Learning. Untuk menyiapkan penerapan Discovery Learning, subyek penelitian sebanyak 35 orang dibagi menjadi 7 kelompok, sehingga masing-masing terdiri dari 5 orang dengan kategori penilaian sangat baik, baik dan kurang sehingga kelompok bersifat heterogen.

2. Paparan Data Siklus I

Kegiatan dalam siklus I terdiri dari perencanaan, tindakan, pengobservasian, dan refleksi yang dilakukan dalam dua kali pertemuan. Pada tahap perencanaan dilakukan penyiapan seluruh perangkat pembelajaran kimia untuk menerapkan model Discovery Learning berupa RPP, LKK, serta instrumen untuk pengambilan data hasil belajar siswa dalam siklus I terdiri dari lembar observasi kegiatan guru, kisi-kisi soal, soal, lembar penilaian kognitif, psikomotorik beserta rubriknya, dan catatan lapangan.

Pada siklus I ada 2 pertemuan. Pada pertemuan 1 siklus I guru mengawali pembelajaran dengan melakukan apersepsi berupa tanya jawab tentang materi redoks. Sebelum siswa membentuk kelompok guru menyampaikan tujuan pembelajaran, pemberian stimulasi (rangsangan) berupa paparan suatu permasalahan terkait konsep sel Volta dan aplikasinya dalam kehidupan sehari-hari dalam bentuk power point. Kemudian dilanjutkan pembentukan 7 kelompok yang masing-masing beranggotakan 5 anak dengan kemampuan heterogen. Guna membantu proses pembelajaran dibagikan LKK 1 yang disusun sesuai sintak-sintak model Discovery Learning pada masingmasing kelompok. Setelah kelompok menyelesaian LKK1, dilanjutkan diskusi kelas ,dimana masing-masing kelompok mempresentasikan hasil diskusi bergantian. Di akhir diskusi kelompok guru mengajak siswa bersama-sama membuat kesimpulan tentang tujuan pembelajaran hari itu. Di akhir pertemuan dilakukan uji pemahaman materi pembelajaran atau hasil belajar siswa lewat ujian formatif (post tes).

Pada pertemuan 2 siklus I guru mengawali pembelajaran dengan melakukan apersepsi berupa tanya jawab tentang materi sel Volta. Sebelum siswa membentuk kelompok guru menyampaikan tujuan pembelajaran, pemberian stimulasi (rangsangan) berupa paparan suatu permasalahan terkait konsep sel Volta komersial dan aplikasinya dalam kehidupan sehari-hari dalam bentuk power point. Kemudian dilanjutkan pembentukan 7 kelompok yang masing-masing beranggotakan 5 anak dengan kemampuan heterogen. Guna membantu proses pembelajaran dibagikan LKK 2 yang disusun sesuai sintak-sintak model Discovery Learning pada masing-masing kelompok. Setelah kelompok menyelesaian LKK2, dilanjutkan diskusi kelas ,dimana masing-masing kelompok mempresentasikan hasil diskusi bergantian. Di akhir diskusi kelompok guru mengajak siswa bersama-sama membuat kesimpulan tentang tujuan pembelajaran hari itu. Di akhir pertemuan dilakukan uji pemahaman materi pembelajaran atau hasil belajar siswa lewat ujian formatif (post tes).

Observasi dilakukan terhadap aktivitas guru dalam penerapan model Discovery Learning secara tepat, baik, lancar yang dilakukan oleh teman sejawat sebagai observer. Hasil observasi aktivitas guru yang dilakukan oleh teman sejawat yang merupakan rata-rata pertemuan 1 dan 2 sebesar $81,50 \%$ dengan kriteria keberhasilan tindakan baik. 
Observasi aktivitas siswa selama mengikuti proses pembelajaran dijaring melalui rubrik penilaian psikomotor yang meliputi keaktifan siswa saat percobaan, pelaksanaan percobaan, laporan percobaan, dan keaktifan siswa saat diskusi kelas. Hasil penilaian psikomotor pertemuan 1 dan 2 ( diambil yang tertinggi dari 2 penilaian) menunjukan 14,29\% kategori penilaian kurang, $80 \%$ kategori penilaian baik, dan $5,71 \%$ kategori penilaian sangat baik. Sehingga $85,71 \%$ siswa mencapai nilai minimal KKM.

Observasi terhadap hasil belajar siswa dilakukan dengan pemberian tes yang dilaksanakan tiap akhir pertemuan. Berdasarkan data nilai rata-rata hasil tes pertemuan 1 dan pertemuan 2 menunjukan 20,00 \% kategori penilaian kurang, 74,29\% kategori penilaian baik, dan 5,71\% kategori penilaian sangat baik. Sehingga $80,00 \%$ siswa mencapai nilai minimal KKM.

Catatan lapangan selama kegiatan pembelajaran dengan model Discovery Learning, pada pertemuan 1 saat percobaan sel Volta pada umumnya memerlukan waktu yang melebihi target. Guru berusaha melayani siswa yang datang atau mendatangi kelompok yang berkonsultasi tentang penggunaan avometer, dengan cara memberikan pertanyaan yang mengarahkan cara penggunaan alat. Pada saat diskusi kelas nampak masih banyak siswa yang mengemukakan pendapat belum lancar, namun ada beberapa siswa yang dapat menjelaskan permasalahan sel Volta dengan bahasa baik dan lancar.

Refleksi dilakukan untuk menentukan apakah siklus I telah berhasil atau tidak, dengan kriteria keberhasilan bila $85 \%$ siswa dalam satu kelas telah mencapai nilai minimal KKM dari aspek pengetahuan maupun ketrampilan. Karena aspek pengetahuan hanya $80,00 \%$ siswa kelas X TITL 2 SMKN 1 Blitar yang telah mencapai nilai minimal KKM, walaupun aspek ketrampilan (psikomotor) sebanyak $85,71 \%$, maka siklus I masih perlu diperbaiki. Perbaikan dilakukan terutama optimalisasi kerja kelompok, agar proses tutor teman sebaya berlajan dengan baik, dan dalam pemecahan masalah secara kelompok, agar pelaksanaan percobaan dan presentasi berjalan lancar, siswa menjadi aktif, kreatif, sharing ilmu antar kelompok dapat berlangsung, dan siswa tidak gaduh.

3. Paparan Data Sikus II

Kegiatan dalam siklus II terdiri dari perencanaan, tindakan, pengobservasian, dan refleksi yang dilakukan dalam dua kali pertemuan. Pada tahap perencanaan dilakukan penyiapan seluruh perangkat pembelajaran kimia untuk menerapkan model Discovery Learning berupa RPP, LKK, serta instrumen untuk pengambilan data hasil belajar siswa dalam siklus II terdiri dari lembar observasi kegiatan guru, kisi-kisi soal, soal, lembar penilaian kognitif, psikomotorik beserta rubriknya, dan catatan lapangan.

Pada siklus II ada 2 pertemuan. Pada pertemuan 1 siklus II guru mengawali pembelajaran dengan melakukan apersepsi berupa tanya jawab tentang materi redoks dan ion-ion yang terdapat dalam larutan elektrolit yang merupakan prasyarat untuk mempelajari sel elektrolisa. Sebelum siswa membentuk kelompok guru menyampaikan tujuan pembelajaran, pemberian stimulasi (rangsangan) berupa paparan suatu permasalahan terkait konsep sel elektrolisa dan aplikasinya dalam kehidupan seharihari dalam bentuk power point. Kemudian dilanjutkan pembentukan 7 kelompok yang masing-masing beranggotakan 5 anak dengan kemampuan heterogen. Guna membantu proses pembelajaran, dibagikan LKK 3 yang disusun sesuai sintak-sintak model Discovery Learning pada masing-masing kelompok. Setelah kelompok menyelesaian LKK3, dilanjutkan diskusi kelas ,dimana masing-masing kelompok mempresentasikan hasil diskusi bergantian. Di akhir diskusi kelompok guru mengajak siswa bersama-sama membuat kesimpulan tentang : (1) pengertian sel elektrolisa, (2) reaksi reduksi dan oksidasi pada sel elektrolisa. Di akhir pertemuan dilakukan uji pemahaman materi pembelajaran atau hasil belajar siswa lewat ujian formatif (post tes).

Pada pertemuan 2 siklus II guru mengawali pembelajaran dengan melakukan apersepsi berupa tanya jawab tentang materi sel elektrolisa. Sebelum siswa membentuk kelompok guru menyampaikan tujuan pembelajaran, pemberian stimulasi 
(rangsangan) berupa paparan suatu permasalahan terkait konsep sel elektrolisa untuk pelapisan logam dan aplikasinya dalam kehidupan sehari-hari dalam bentuk power point. Kemudian dilanjutkan pembentukan 7 kelompok yang masing-masing beranggotakan 5 anak dengan kemampuan heterogen. Guna membantu proses pembelajaran dibagikan LKK 4 yang disusun sesuai sintak-sintak model Discovery Learning pada masing-masing kelompok. Setelah kelompok menyelesaian LKK4, dilanjutkan diskusi kelas ,dimana masing-masing kelompok mempresentasikan hasil diskusi bergantian. Di akhir diskusi kelompok guru mengajak siswa bersama-sama membuat kesimpulan tentang : (1) elektroda dan larutan elektrolit yang digunakan pada pelapisan logam. Di akhir pertemuan dilakukan uji pemahaman materi pembelajaran atau hasil belajar siswa lewat ujian formatif (post tes).

Observasi dilakukan terhadap aktivitas guru dalam penerapan model Discovery Learning secara tepat, baik, lancar yang dilakukan oleh teman sejawat sebagai observer. Hasil observasi aktivitas guru yang dilakukan oleh teman sejawat yang merupakan rata-rata pertemuan 1 dan 2 sebesar 92,00\% dengan kriteria keberhasilan tindakan sangat baik.

Observasi aktivitas siswa selama mengikuti proses pembelajaran dijaring melalui rubrik penilaian psikomotor yang meliputi keaktifan siswa saat percobaan, pelaksanaan percobaan, laporan percobaan, dan keaktifan siswa saat diskusi kelas. Hasil penilaian psikomotor pertemuan 1 dan 2 ( diambil yang tertinggi dari 2 penilaian) menunjukan 5,71\% kategori penilaian kurang, $80 \%$ kategori penilaian baik, dan $14,29 \%$ kategori penilaian sangat baik. Sehingga $94,29 \%$ siswa mencapai nilai minimal KKM.

Observasi terhadap hasil belajar siswa dilakukan dengan pemberian tes yang dilaksanakan tiap akhir pertemuan. Berdasarkan data nilai rata-rata hasil tes pertemuan 1 dan pertemuan 2 menunjukan 8,57 \% kategori penilaian kurang, 82,86\% kategori penilaian baik, dan $8,57 \%$ kategori penilaian sangat baik. Sehingga $91,43 \%$ siswa mencapai nilai minimal KKM.

Catatan lapangan pada siklus II baik pertemuan 1 maupun 2 sebagian besar kelompok bekerjasama dengan baik dan lebih mandiri dalam melaksanakan percobaan, sehingga dapat menyelesaikan tugas dalam waktu kurang dari yang ditargetkan. Pada saat diskusi kelas lebih banyak siswa yang mengemukakan pendapat dengan bahasa yang baik dan lancar.

Refleksi dilakukan untuk menentukan apakah siklus II telah berhasil atau tidak, dengan kriteria keberhasilan bila $85 \%$ siswa dalam satu kelas telah mencapai nilai minimal KKM dari aspek pengetahuan maupun ketrampilan. Pada aspek pengetahuan sebanyak 91,43\% siswa kelas X TITL 2 SMKN 1 Blitar yang telah mencapai nilai minimal KKM, sedangkan aspek ketrampilan (psikomotor) sebanyak 94,29\%. Karena jumlah siswa yang mencapai nilai minimal KKM pada aspek pengetahuan dan ketrampilan lebih dari $85 \%$, maka pada siklus II pembelajaran dengan model Discovery Learning dikatakan berhasil dan tidak perlu dilanjutkan ke siklus III.

\section{PEMBAHASAN}

Dari hasil observasi terhadap kegiatan guru dalam penerapan model Discovery Learning pada siswa kelas X TITL2 SMKN 1 Blitar dari siklus I ke siklus II menunjukan guru dapat menerapkan model Discovery Learning dengan baik pada siklus I dengan rata-rata keberhasilan $81,50 \%$. Sedangkan pada siklus II menghasilkan peningkatan sebesar $10,50 \%$ dengan ditunjukan oleh rata-rata keberhasilan sebesar $92,00 \%$ (sangat baik).

Penilaian hasil belajar kimia siswa meliputi aspek ketrampilan dan pengetahuan. Peningkatan hasil belajar kimia siswa kelas X TITL 2 SMKN 1 Blitar aspek ketrampilan dari siklus I ke siklus II menunjukan adanya peningkatan jumlah siswa yang mencapai nilai minimal KKM sebesar 8,58\% (dari 85,71\% menjadi $94,29 \%$ ). Dan pada siklus II kategori penilaian terbagi menjadi $5,71 \%$ kategori 
JURNAL PENDIDIKAN: Riset dan Konseptual, Vol. 3 No. 2, April 2019 www.journal.unublitar.ac.id/ip E-ISSN: 2598-2877

P-ISSN: 2598-5175

penilaian kurang, $80 \%$ kategori penilaian baik, dan 14,29\% kategori penilaian sangat baik.

Peningkatan hasil belajar kimia siswa kelas X TITL 2 SMKN 1 Blitar aspek pengetahuan dari siklus I ke siklus II menunjukan adanya peningkatan jumlah siswa yang mencapai nilai minimal KKM sebesar $11,43 \%$ (dari $80,00 \%$ menjadi $91,43 \%$ ). Dan pada siklus II kategori penilaian terbagi $8,57 \%$ kategori penilaian kurang, 82,86\% kategori penilaian baik, dan 8,57\% kategori penilaian sangat baik.

Dari hasil pembahasan di atas jelaslah bahwa hasil belajar kimia pada sel elektrokimia siswa kelas X TITL 2 SMKN 1 Blitar dapat ditingkatkan melalui penerapan model Discovery Learning.

\section{KESIMPULAN}

Dari hasil pembahasan di atas maka dapat disimpulkan : (1) model Discovery Learning dapat diterapkan pada pembelajaran kimia siswa pada sel elektrokimia kelas $X$ TITL2 SMKN 1 Blitar, (2) hasil belajar kimia siswa pada sel elektrokimia kelas $X$ TITL2 SMKN 1 Blitar dapat ditingkatkan melalui penerapan model Discovery Learning.

\section{SARAN}

Dari hasil penelitian ini kami sarankan : (1) bagi Peneliti, hasil penelitian ini dapat dijadikan sebagai masukan untuk meningkatkan proses pembelajaran kimia di kelas pada masa mendatang, khususnya untuk materi sel elektrokimia, (2) Setiap siswa menjadi lebih aktif dalam proses pembelajaran baik saat melaksanakan percobaan, kerja kelompok, membuat laporan, dan diskusi kelas, sehingga mampu menemukan sendiri konsep-konsep yang dipelajari dan hasil belajar meningkat, (3) bagi guru atau peneliti lain, dapat dijadikan acuan dalam melakukan penelitian sejenis, atau yang akan mencoba menerapkan model Discovery Learning di kelasnya. Sehingga mereka bisa mempersiapkan lebih dulu semua instrumen yang dibutuhkan dengan baik, (4) Bagi sekolah, hasil penelitian ini dapat dijadikan acuan dalam membuat kebijakan tentang peningkatan kualitas sekolah, seperti penyediaan sarana praktek untuk siswa, dan pengembangan keprofesian berkelanjutan bagi guru.

\section{DAFTAR RUJUKAN}

Akbar, S. 2010.Penelitian Tindakan Kelas Filosofi, Metodologi \& Implementasi.Yoyakarta: Cipta Media Aksara.

Arends, R. Learning To Teach. Terjemahan oleh Helly Prajitno Soetjipto. 2004. Yogyakarta: Pustaka Pelajar.

Kemendikbud. 2014. Materi Pelatihan Guru Implementasi Kurikulum 2013 Tahun Ajaran 2014/2015. Jakarta: Badan Pengembangan Sumber Daya Manusia Pendidikan dan Kebudayaan dan Penjaminan Mutu Pendidikan.

Kemendikbud. 2017. Panduan Penilaian Hasil Belajar pada Sekolah Menengah Kejuruan. Jakarta: Dirjen Dikdasmen.

Wijayati, E. 2016. Penerapan Metode Discovery Terpimpin untuk Meningkatkan Motivasi dan Hasil Belajar Senyawa Hidrokarbon. Jurnal Hasil Penelitian. Surabaya: Media Jawa Timur. 